\title{
HIV/HCV coinfection in Infectious Disease Units in Mozambique and Brazil: a comparative study
}

\author{
A co-infecção HIV/HCV em Serviços de Doenças Infecciosas \\ de Moçambique e do Brasil: estudo comparativo
}

\section{Dear Editor:}

The prevalence of human immunodeficiency virus/ hepatitis $\mathrm{C}$ virus (HIV/HCV) coinfection has been reported for Brazil ${ }^{2}$ and for some Sub-Saharan African countries ${ }^{14}$, but no data is available from Mozambique. Here, we report preliminary prevalence data and present the profile of HIV/HCV coinfected patients from an Infectious Disease Unit in Maputo, Mozambique, and from an equivalent Infectious Disease Unit in Belo Horizonte, Brazil.

Three hundred patients attending an outpatient clinic in Mozambique and 300 from an outpatient clinic in Brazil, within the age range of 18 to 65 years, were selected for this study between November 2006 and July 2007. A standardized sociodemographic and epidemiological questionnaire was used to record the information, which subsequently was transferred to a database in the Epi-Info software. Serum from Mozambicans and Brazilians was stored at $-20^{\circ} \mathrm{C}$. HIV infection was diagnosed by an ELISA technique (enzyme-linked immunosorbent assay) and was confirmed by Western blotting, and HCV was diagnosed by the ELISA MEIA (AXSYMG HCV 3.0) and confirmed by a polymerase chain reaction (PCR) (Amplicor 3.0, Roche). Sequencing and genotyping were then performed to identity virus subtypes using an automatic sequencer (Applied Biosystems).

The prevalences of HIV/HCV coinfection in Mozambicans and Brazilians were $15.7 \%$ and $10 \%$, respectively $(\mathrm{p}=0.04)$. Coinfection was also more frequent among Mozambican women, and this roughly coincided with the gender distribution of HIV infection in Mozambique (3:1 female/male ratio in the age range of 20 to 24 years). The mean T CD $4+$ cell counts were: 253 cells $/ \mathrm{mm}^{3}(\mathrm{SD}=169)$ and $400(\mathrm{SD}=244)$ for Mozambicans and Brazilians, respectively $(\mathrm{p}<0.01)$. The risk factors for HCV infection among Mozambicans and Brazilians were, respectively: $0 \%$ and $40 \%$ for illegal intravenous drug use; $14.9 \%$ and $20 \%$ for blood transfusion; $0 \%$ and $16 \%$ for homosexual activity; $100 \%$ and $76.6 \%$ for heterosexual activity; $8.5 \%$ and $36.6 \%$ for other factors (tattooing, piercing, imprisonment and occupational risk). The HCV genotypes identified in Mozambique were 1a, 2a, 4 and $5 \mathrm{a}$, whereas in Brazil, they were $1 \mathrm{a}, 1 \mathrm{~b}$ and $3 \mathrm{a}$.

In short, the prevalence of hepatitis $\mathrm{C}$ among HIV-infected patients was higher among Mozambicans. The unexpected differences in the data on homosexual behavior and in the use of illegal intravenous drugs between the populations evaluated raise the issue of the quality of the information obtained in the African country. There was a marked difference in HCV genotypes between the study groups. Preliminary analysis on the treatment of hepatitis C in the two populations revealed that only $8.5 \%$ of the Mozambicans and $10 \%$ of the Brazilians presenting HIV/HCV coinfection would be eligible candidates for hepatitis $\mathrm{C}$ treatment.

\section{REFERENCES}

1. Agwale SM, Tanimoto L, Womack C, Odama L, Leung K, Duey D, Negedu-Momoh R, Audu I, Mohammed SB, Inyang U, Graham B, Ziermann R. Prevalence of HCV co-infection in HIV-infected individuals in Nigeria and characterization of HCV genotypes. Journal of Clinical Virology 31 (suppl 1): S3-S6, 2004.

2. Mendes-Corrêa MC, Barone AA, Guastini C. Hepatitis C virus seroprevalence and risk factors among patients with HIV infection. Revista do Instituto de Medicina Tropical de São Paulo 43: 15-19, 2001.

3. Nobre V, Braga E, Rayes A, Serufo JC, Godoy P, Nunes N, Antunes CM, Lambertucci JR. Opportunistic infections in patients with AIDS admitted to an university hospital of the Southeast of Brazil. Revista do Instituto de Medicina Tropical de São Paulo 45: 69-74, 2003.

4. Sutcliffe S, Taha TE, Kumwenda NI, Taylor E, Liomba GN. HIV-1 prevalence and herpes simplex virus 2, hepatitis $\mathrm{C}$ virus, and hepatitis B virus infections among male workers at a sugar estate in Malawi. Journal of Acquired Immune Deficiency Syndromes 31: 90-97, 2001.

\section{Maria da Conceição Viana Rodrigues ${ }^{1}$, Júlia Bini Viotti ${ }^{2}$, Renata Felício Braga ${ }^{2}$, Lívia Flávia Sebe Lourenço ${ }^{2}$, Carlos Maurício de Figueiredo Antunes ${ }^{2}$ and José Roberto Lambertucci ${ }^{2,3}$}

\footnotetext{
1. Hospital Central de Maputo, Maputo, Mozambique. 2. Pós-Graduação em Ciências da Saúde: Infectologia e Medicina Tropical, Faculdade de Medicina, Universidade Federal de Minas Gerais, Belo Horizonte, MG. 3. Núcleo de Ações e Pesquisa em Apoio Diagnóstico, Faculdade de Medicina, Universidade Federal de Minas Gerais, Belo Horizonte, MG. Partially financial support: NUPAD (Núcleo de Ações e Pesquisa em Apoio Diagnóstico, Faculdade de Medicina, Universidade Federal de Minas Gerais.

Address to: Dr. José Roberto Lambertucci. NUPAD/FM/UFMG. Av. Alfredo Balena 190, 30130-100 Belo Horizonte, MG.

e-mail: lamber@uai.com.br

Recebido para publicação em 16/09/2008

Aceito em: 26/08/2008
} 